\title{
KAKO SMO POSTALI JUGOSLAVENI: \\ O ETNIČKIM/NACIONALNIM IDENTITETIMA HRVATA U \\ ČILEU I ARGENTINI ZA VRIJEME PRVOGA SVJETSKOG RATA
}

\author{
MARINA PERIĆ KASELJ \\ Institut za migracije i narodnosti \\ 10000 Zagreb, Trg Stjepana Radića 3 \\ marina.peric@imin.hr
}

\author{
DOI: 10.17234/SEC.28.9 \\ Izvorni znanstveni rad \\ Primljeno: 6. 6. 2016. \\ Prihvaćeno: 25. 6. 2016.
}

Ovaj rad nalazi se u otvorenom pristupu i može se distribuirati u skladu s odredbama licencije CC BY-NC-ND 4.0 HR

Prvi svjetski rat $i$ događaji koji su uslijedili tijekom i nakon rata imali su snažan utjecaj na kolektivne identifikacije iseljenika. Nacionalno samoodređenje Hrvata unutar ili izvan Monarhije, na trijalističkoj osnovi s Austro-Ugarskom ili u zajednici s južnoslavenskim narodima, nametale su se kao dominantne nacionalne ideologije u domovini. Takva politička situacija preslikavala se i među iseljeničkim zajednicama u Čileu i Argentini. Događaj poput Prvoga svjetskog rata mijenja kolektivne identifikacije i strategije hrvatskih iseljenika u Čileu i Argentini, a putem iseljeničkog tiska i iseljeničkih društava propagira se nova nacionalna definicija i južnoslavenska koncepcija buduće države te se osniva iseljenički pokret Jugoslavenska narodna obrana (JNO) u Južnoj Americi. Koristeći iseljenički tisak kao izvor u svrhu pronalaženja dominantnih diskursa u oblikovanju kolektivne svijesti iseljenika, u radu nastojimo odgovoriti na pitanja kako su događaji u domovini, prije svega Prvi svjetski rat, utjecali na kolektivne identifikacije iseljenika u Čileu i Argentini, te analiziramo faktore koji su doprinijeli snažnim odobravanjem i participacijom iseljenika u Čileu u iseljeničkom pokretu JNO-a (za razliku od iseljenika u Argentini) kao i njihovu ulogu u stvaranju buduće Kraljevine SHS / Jugoslavije.

Ključne riječi: hrvatski iseljenici, Čile, Argentina, Prvi svjetski rat, etnički/nacionalni identitet, iseljenički pokret, Jugoslavenska narodna obrana

\section{UVOD}

Govoriti o nacionalnom identitetu hrvatskih iseljenika za vrijeme Prvoga svjetskog rata ne može se bez analize širega društveno-povijesnog konteksta razdoblja njihova masovnog iseljavanja u Čile i Argentinu. Stoga je, zbog lakšeg praćenja političke situacije među iseljenicima za vrijeme Prvoga svjetskog rata, potrebno razmotriti i opisati prethodno razdoblje od 
kraja 19. stoljeća do Prvoga svjetskog rata. Proces iseljavanja u Argentinu i Čile započeo je iz priobalnih prostora i otoka znatno prije nego iz ostalih dijelova Hrvatske. Iz Dalmacije se do 1910. godine iselilo 92000 ljudi (Usp. Banović 1987; Lakatoš 1914). Pokrajina Dalmacija zajedno je s Istrom Hrvatsko-ugarskom nagodbom iz 1867. godine pripala austrijskom dijelu Austro-Ugarske Monarhije. Odvojenost i slabe veze sa zaleđem bile su jedan od uzroka gospodarske nerazvijenosti Dalmacije. Od 17 austrijskih pokrajina Kraljevina Dalmacija po broju stanovnika bila je na desetom mjestu, te je bila znatno slabije napučena od ostalih dijelova Austrije. Samo jedna petina površine bila je obrađena i nalazila se pod kulturama, dok je sve ostalo zemljište bilo uglavnom neplodno, a sastojalo se od krševitih pašnjaka i dalmatinskih šuma (Diklić 1998:14). Iseljavanja iz Dalmacije do Prvoga svjetskog rata odvijala su se u dva karakteristična migracijska vala. Inicijalne (rane) migracije do 1890. godine, tzv. migracijsko buđenje, bile su sporadične i uglavnom su iseljavali pomorci. To su bile slabe migracije i razlikovale su se od masovnih migracija na prijelazu stoljeća (1890.1914.) koje su bile karakteristične za migrantske grupe s vrlo sličnim socijalno-demografskim i ekonomskim karakteristikama (Lajić 1992:137). Iseljavanje su uzrokovali gospodarski (ekonomski) i neekonomski čimbenici (prenaseljenost otoka, kriza vinogradarstva, seljački dugovi, propast jedrenjaštva i dr.). Od neekonomskih, najčešći uzrok migracija bio je vojno-politički. Godine 1852. Austrija je prvi put provela popis vojnih obveznika. Mlađe stanovništvo Dalmacije našlo se u situaciji da bude pozvano na dugotrajno služenje vojnog roka.

Hrvatskisuiseljenicikao austrijskipodaniciupopisimajužnoameričkih država uglavnom klasificirani kao "Austriacos" ili rjeđe "Austroungaros". Osnivali su svoje kolonije pod austrijskim/austrougarskim imenom, a svoja društva imenovali kao austrijska (Čile) ili austrougarska društva (karakteristična za Argentinu gdje se osim Dalmatinaca iseljavaju i Hrvati iz pokrajine Hrvatske, Slavonije i Istre). Kolonije hrvatskih iseljenika službeno su zastupali novoosnovani austrijski konzulati, a konzulima su imenovani Nijemci ili Talijani čiji jezik većina iseljenika nije razumjela. Prema riječima iseljenika, konzuli su se prema njima ponašali kao prema "inferiornoj rasi" (dopisi iseljenika, Narodni list, 23. lipnja 1897., 19. kolovoza 1903.). 
Političke prilike preslikavale su se iz Dalmacije, društva podrijetla, na odnose među iseljenicima. Kao austrijski podanici dalmatinskog podrijetla odvojeni od hrvatskih zemlja, iseljenici su bili pod utjecajem dviju političkih struja: narodnog pokreta, zbog čega se razvijala nacionalna svijest o pripadnosti hrvatskom narodu, i autonomaške stranke koja je zagovarala samostalnu Dalmaciju (ova politička struja bila je popularna među Austrijakima, dobno starijim, ali uglavnom ekonomsko imućnim iseljenicima).

Naime, utjecajni iseljenici (kako u čileanskom i argentinskom društvu tako i unutar iseljeničkih zajednica) koji su odselili u Čile i Argentinu sredinom 19. stoljeća u vrijeme prosperiteta otoka, bili su pustolovi, pomorci, istraživači, i uglavnom autonomaški nastrojeni braneći političku ideju samostalne Dalmacije u okviru Monarhije. Oni su činili nukleuse hrvatskih iseljeničkih zajednica u čijim su se trgovinama, industrijskim postrojenjima i brodovima zapošljavali novi iseljenici. Tako su imali izravan utjecaj na značajan broj članova iseljeničkih zajednica.

Jačanjem narodnog pokreta u domovini, narodnjaka i pravaških političara Ante Starčevića i Ante Trumbića, dolazi do mijenjanja naziva društava ali i naziva hrvatskih iseljeničkih kolonija. Početkom 20. stoljeća $\mathrm{u}$ skladu s političkim procesima u domovini većina hrvatskih iseljeničkih društava mijenja prvobitna austrijska ili austrougarska imena u hrvatska ili slavjanska/slavenska iako usporedno još uvijek egzistiraju i društava s austrijskim nazivima. Prvo društvo jugoslavenskog naziva i programa (dok Jugoslavija još nije ni postojala) osnovano je u Argentini pod nazivom Društvo iseljenih Jugoslavena za materinsku riječ. U svoje članstvo društvo je osim Hrvata nastojalo okupiti Srbe i Slovence, a izdavali su i vlastiti tjednik Materinska riječ. Programski je zagovaralo jedinstvo Hrvata, Srba i svih slavenskih naroda, a predstavljalo su pod imenom glavni organ južnoslavenske iseljeničke zajednice u Južnoj Americi. Dok je u Dalmaciji zbog Balkanskih ratova vladalo "jugoslavensko raspoloženje", a u Srbiji se tražio oslonac i podrška u razbijanju Monarhije, u iseljeništvu Južne Amerike razvijalo se slično raspoloženje. Iseljenici su se, prateći događaje u vezi s Balkanskim ratovima, solidarizirali sa Srbima i Crnogorcima i njihovom borbom protiv Osmanskog Carstva te težnjama za nacionalnim samoodređenjem. Posredstvom središnjeg odbora u Zadru 
novčano su pomagali Crveni križ u Beogradu i Cetinju. Godine 1912. ulogu koordinatora za sakupljanje pomoći za Crveni križ Srbije, Crne Gore i Bugarske imao je Valparaíso koji je bio centar gdje se sabirao novac iseljenika iz središnjeg, sjevernog i južnog Čilea. U Argentini je osnovan glavni odbor za pripomoć srpsko-crnogorskom Crvenom križu u Rosariju 1912. godine, koji je koordinirao iseljeničke akcije iz Argentine i Čilea za pomoć srpskim i crnogorskim vojnicima na ratištu. Premda tada iseljenici sve više zastupaju ideju zajedničke borbe južnih Slavena protiv AustroUgarske, događaji poput atentata na Franju Ferdinanda, a ubrzo i Prvi svjetski rat, uzrokovat će kolebanje i ponovne podjele među iseljenicima. Veći dio hrvatskih iseljenika od tada će prihvaćati jugoslavenstvo i sebe će nazivati i smatrati Jugoslavenima. Značajan broj njih, pogotovo u Čileu, uključit će se u iseljenički pokret Jugoslavenska narodna obrana (JNO). Kako je u Argentini, za razliku od Čilea (u kojem je bilo gotovo homogeno hrvatsko/dalmatinsko iseljeništvo), osim Hrvata, i to ne samo iz Dalmacije nego i Slavonije i Hrvatske, bio i značajan broj Srba, Crnogoraca, Slovenaca te ostalih slavenskih naroda, smatramo kako je nacionalna pripadnost utjecala na oblik i intenzitet identifikacije s JNO-om, prihvaćanje ideje jugoslavenstva te stvaranja zajedničke države Jugoslavije. Najjači otpor jugoslavenstvu u hrvatskim iseljeničkim zajednicama pokazat će se u Argentini i prema uvidu i analizi dostupnih izvora mogli bismo reći kako su ti iseljenici uglavnom bili okupljeni oko utjecajnog iseljenika Nikole Mihanovića, ali i urednika iseljeničkih novina Zajednica i predsjednika Hrvatskog saveza Ivana Radeljaka, o čemu će u nastavku biti više riječi.

\section{ATENTAT NA FRANJU FERDINANDA: REAKCIJE U ISELJENIŠTVU}

Atentat Gavrila Principa ${ }^{1}$ na prijestolonasljednika Franju Ferdinanda u Sarajevu 28. lipnja 1914. godine izazvao je niz burnih reakcija u Monarhiji koje su prouzrokovale krajnje negativan i isključiv stav jednog dijela

\footnotetext{
${ }^{1}$ Bio je pripadnik terorističke organizacije Mlada Bosna, organizirane i vođene iz Srbije. Austro-Ugarska je zatražila da srpski inspektori obave istragu o atentatu na srpskom teritoriju što je Srbija odbila. Austrija je objavila rat Srbiji, Rusija navijestila rat AustroUgarskoj. Potom se uključila Njemačka na strani Austro-Ugarske, a Velika Britanija i Francuska na strani Srbije i Rusije (Goldstein 2003:226).
} 
Hrvata (uglavnom frankovaca ${ }^{2}$ i njihovih pristaša) Monarhije prema Srbiji i srpskom narodu. Nakon toga događaja, potreseni i razočarani frankovci organizirali su protusrpske demonstracije diljem zemlje. ${ }^{3}$

U Argentini (istovjetno nekim krugovima u domovini) u iseljeničkim novinama Zajednica 4 u nekoliko se članaka osuđuje atentat na Franju Ferdinanda i zauzima pozitivan/obrambeni stav prema Austro-Ugarskoj Monarhiji. Tom su prilikom u ime sućuti i novine izdane u posebnom "crnom" izdanju. Ovakvo pisanje izazvalo je negativnu reakciju jednog dijela Hrvata u Čileu. Nakon što su primili i čitali navedeni broj Zajednice, iseljeničke novine Domovina iz Čilea uputile su brzojav u kojem "u ime uvrijeđenog hrvatskog nacionalnog dostojanstva" prosvjeduju protiv takvog pisanja. Poslan je i brzojav iseljeničkom listu Sloboda i Slavenskoj

\footnotetext{
${ }^{2}$ Frankovci su naziv za frakciju pravaša koji su 1890. godine osnovali svoju Čistu stranku prava na čelu s Josipom Frankom. Imali su suradnju s bečkim dvorom, u cilju da se, nasuprot Mađarima, ostvare hrvatski nacionalni interesi u okviru Monarhije - trijalističko uređenje Monarhije (hrvatska bi jedinica obuhvatila Sloveniju, Hrvatsku, Bosnu i Hercegovinu te Vojvodinu).

${ }^{3}$ Nakon toga je došlo do drugih izgreda: bačen je kamen na povorku sa slikom Franje Ferdinanda nakon čega su demolirane radnje u vlasništvu Srba u Zagrebu te kavane i okupljališta projugoslavenskih političara. Napadnuti su i saborski zastupnici Hrvatskosrpske koalicije. Socijaldemokratska stranka održala je skup na kojem je osuđeno protusrpsko raspoloženje. Protusrpske demonstracije održane su u Beču, Budimpešti i mnogim hrvatskim gradovima gdje su napadane srpske udruge i društva, a došlo je i do sukoba sa Srbima i projugoslavenski orijentiranim građanima (vidi više: Agičić 1996; Karaula 2011).

${ }^{4}$ Urednik novina Ivan Radeljak bio je utemeljitelj društva Hrvatski skup u Taltalu, u čileanskoj pokrajini Antofagasti. Društvena zastava bila je hrvatski barjak. Društvo je posjedovalo velike prostorije ukrašene sa 18 velikih slika iz slavne hrvatske prošlosti. U društvu je bila i kuglana. Društvo je javno istupilo protiv austrijske vlade, posebice oko postavljanja njemačkog konzula za predstavnika: “Cilj i svrha ovog društva jesu: čuvati i gajiti među družinarima hrvatsko-slavenskoga podrijetla sveto narodno čuvstvo, bratsku slogu i ljubav [...] Društvena zastava je Hrvatska [...] Poznavanjem naših iseljenika imenom Croata znači mnogo [...] označuje pobjedu nad zapostavljanjem našeg pravog narodnog imena u ovoj dalekoj tuđini" (Jeka, Rosario, 3. dio, 1910:38). Reemigrirao je iz Čilea u Argentinu (u Rosario) te bio urednik i izdavač iseljeničkih novina Zajednica (od 1910.). Radeljak je izdajući novine Zajednica u Rosariju imao namjeru da putem novina okupi hrvatske iseljenike diljem Južne Amerike. Imao je dopisnike iz raznih područja Argentine, Čilea, Bolivije, Perua, Brazila, Urugvaja i Paragvaja.
} 
misli u Argentini: "Radeljak proglašen narodnim izdajicom i varalicom, bojkot potpuni njemu i Zajednici” (Domovina, 16. kolovoza 1914.). Osuđujući urednika novina Zajednica Radeljaka, iseljeničke novine Pokret pisale su: "Već od prvog broja, počela je Zajednica da navaljuje na srpski nam bratski narod, okrivljujući ga izravno, kao krivca, bez da je ikada nepristrano ispitala i proučila, te istumačila njezin pravi uzrok. Kad se je navijestio srpsko austrijski rat, a za njim evropejski rat i tim borbama na život ili smrt Slavenstva protiv Germanstva, Zajednica je počela, da šara sad bijelo sad crno" (Pokret, 10. siječnja 1915.).

Nakon što se Zajednica svojim prilozima svrstala u obranu AustroUgarske Monarhije (u slučaju atentata u Sarajevu), okarakterizirat će je kao novine "austrijskih plaćenika" i izdajicu Radeljaka (Domovina, 1914). Čileanska Domovina stoga će je imenovati organom frankovački orijentiranih Hrvata koji glorificiraju Austriju te se protive Srbima i Srbiji. Radeljakova Zajednica oštro je pak napadala Slobodu, ${ }^{5}$ službeno glasilo Hrvatske straže. Radeljak je smatrao negativnim što Sloboda zagovara i propagira jugoslavenstvo kao nacionalnu strategiju na štetu hrvatskog imena, a time i hrvatskoga nacionalnog identiteta.

\section{PRVI SVJETSKI RAT: POZIV MONARHIJE NA MOBILIZACIJU HRVATSKIH ISELJENIKA}

Nagovještaj rata, potreba za mobilizacijom u svrhu okupljanja, jačanja i zadržavanja vojnih snaga Austro-Ugarske Monarhije rezultirala je restriktivnim zakonima Monarhije i zabrani iseljavanja osobama mlađima od 16 godina. Hrvatske zemlje unutar Monarhije našle su se u ratu s još uvijek nerazjašnjenom koncepcijom buduće nacionalne države. ${ }^{6}$ Od Balkanskih se

\footnotetext{
${ }^{5}$ Novine Sloboda izlazile su u Buenos Airesu od 1913. do 1915. godine. Zagovarale su jugoslavenski program. Nasljednik su novine Jadran čiji prvi broj izlazi 1916. godine pod uredništvom Ljube Leontića.

${ }^{6}$ Supilo (koji je izašao iz Hrvatsko-srpske koalicije) uoči rata optužio je srpsku politiku u Hrvatskoj, odnosno Svetozara Pribićevića zbog suradnje s banom Tomašićem i mađarskim predsjednikom vlade Khuenom i njegovim kritikama da Hrvatska traži autonomiju u sklopu Monarhije kojima samo potiče srpski ekskluzivizam, a time pojačava i hrvatski ekskluzivizam (pravaše i klerikalce). Zalagao se za skupljanje južnoslavenskih naroda oko Hrvatske (Ganza-Aras 1992:351-359). Hrvatsko-srpska koalicija u središte je pozornosti stavljala jedinstvo Hrvata i Srba smatrajući da nije moguće modificirati
} 
ratova popularizira, poglavito u Dalmaciji među mlađom generacijom, južnoslavenska nacionalna ideologija koja je definiciju nacije postavljala u okvir: južni Slaveni = jedan narod = jedna država. Riječ je o koncepciji buduće države utemeljene na programu jugoslavenskoga unitarističkog nacionalizma čijem je utjecaju pridonijela Jugoslavenska ujedinjena omladina (JUO), nezadovoljna oportunističkom politikom Hrvatsko-srpske koalicije, koja se iz banske Hrvatske povezala s organizacijama omladine $\mathrm{u}$ Bosni i Hercegovini, Dalmaciji i Sloveniji.

Velik broj dalmatinskog stanovništva mobiliziran je u vojsku pod austrougarskom zastavom. ${ }^{7}$ Emigranti, prebjegli iz Monarhije, nastavljali su svoj politički rat oko oslobođenja domovine u inozemstvu (emigraciji).

Proglašenjem rata, austrougarski konzulat u Buenos Airesu izdao je proglas pripadnicima/podanicima Austro-Ugarske Monarhije radi mobiliziranja dobrovoljaca koji bi stupili u njezinu obranu. Na proglas je reagiralo iseljeničko društvo Hrvatska straža ${ }^{8}$ iz Argentine koje je zbog toga sazvalo protestnu narodnu skupštinu Srba i Hrvata 3. kolovoza 1914. na kojoj je izdan Manifest svim Slavenima Monarhije:

U osjećanju naše domovinske ljubavi, u času borbe na život i smrt između Slavenstva i svenijemstva, ne može biti dvojbe niti o našim simpatijama, niti o našem držanju. Ako smo pod teškom rukom Habsburgovaca bili 400 godina prisiljeni da šutimo na sve nepravde i uvrede, što su našem slavenskom narodu nanesene, sada je kucnuo odlučan čas odmazde ... (Leontić 1961:84).

Manifestom su svi Slaveni Monarhije pozvani na okupljanje i zajedničko djelovanje. Stavljen je naglasak na potrebu organiziranja

Monarhiju i da ju je potrebno razbiti, ali je ipak zastupala oportunističku politiku. Čista stranka prava nakon atentata vodila je protusrpsku kampanju i do kraja rata zastupala je ideju hrvatske države u sastavu Monarhije.

${ }^{7}$ Austro-Ugarska Monarhija imala je veliku i naoružanu, uvježbanu vojsku, ali najveći nedostatak bio joj je višeetnički sastav. Časnici su uglavnom bili Austrijanci i Nijemci, a vojnici su pripadnici manjih naroda unutar Austro-Ugarske, stoga joj je nedostajalo borbenog morala jer se vojnici nisu željeli boriti za Monarhiju. U ratu je imala najveći broj ratnih bjegunaca - dezertera (Oršolić 2006).

${ }^{8}$ Prema riječima Ljube Leontića, na spomenutoj skupštini prisustvovali su sve sami hrvatski useljenici, "prvi glasnici revolucionarnog pokreta". 
dobrovoljačkih četa ${ }^{9}$ koje bi bile upućene u Europu, a ratovale bi u Monarhiji u sklopu srpske ili francuske vojske (na strani Saveznika). Daljnji ciljevi bili su uspostavljanje što boljih komunikacijskih veza sa srpskim, ruskim, francuskim i engleskim kolonijama te osnivanje stalnog odbora za sakupljanje pomoći za srpski Crveni križ (Leontić 1961:84). Manifest je označio političku volju dijela iseljenika, s namjerom uključivanja šire zajednice - Slavena u iseljeništvu - u ratna zbivanja u cilju nacionalnog oslobođenja slavenskih naroda Monarhije (Monarhija i Hrvatska postavljene su u širem kontekstu: germanstvo naprama slavenstvu). Odbijanje poziva austrougarskog konzula i Manifesta predstavljaju političku neposlušnost prema austrijskom konzulatu ili Monarhiji (vlasti u domovini). Rat je shvaćen u kontekstu obračuna s višestoljetnim vladarom i neprijateljem Habsburgovcima. Za razliku od opisanih iseljenika koji su definirali svoj stav prema ratu u kontekstu jedinstvenog istupa Slavena (iako su ovdje ponajprije mislili na Srbe i bili priklonjeni Rusiji kao moćnom srpskom savezniku) protiv Monarhije, postojala je i druga grupa iseljenika koja je drugačije shvaćala i doživjela rat u Monarhiji. Naime, takvi iseljenici (okupljeni u Argentini oko urednika lista Zajednica Radeljaka, a možemo sa sigurnošću tvrditi i utjecajnog iseljenika Nikole Mihanovića) smatrali su kako je rat Srbije protiv Monarhije zapravo i rat protiv Hrvatske, te je postojala izvjesna bojazan kako je riječ o velikosrpskoj ideologiji i pretenziji Srbije da zauzme hrvatski teritorij. Takav nam stav ilustrira i sljedeći primjer:

U Spljetu, Dalmaciji, kao Hrvat kao junak podlegao je na bojnom polju, srpska ubojita kugla pogodila ga u glavu, mlad Hrvat, skoro navršio svoju 21 godinu [...] Poginuo je kao junak jer se junački borio za svoju domovinu Hrvatsku i njezina prava: Hrvatska Hrvatima [...] U domovini Hrvati ginu u obrani svoje domovine, a ovdje u slobodnoj Americi neki vajni Hrvati kupe milodare baš za one, koji Hrvate biju, koji hrvatske kuće ruše i pljačkaju [...] Jadna im majka, a još jadnije njihovo hrvatstvo (Zajednica, 17. listopada 1914.).

\footnotetext{
${ }^{9}$ Jugoslavenski odbor (JO) namjeravao je osnovati Jadransku legiju preko koje bi Južni Slaveni u sklopu Monarhije pred saveznicima bili predstavljeni kao vojni faktor, i tako se osloniti na Srbiju. Srpska vlada nije se složila s tom odlukom jer nije htjela da se Južni Slaveni sami oslobode Austrije i tako steknu određena prava pri stvaranju buduće države, a nije se slagala ni oko naziva Legije. Leontić je prvi pokrenuo akciju oko prikupljanja dobrovoljaca u Južnoj Americi (Usp. Antić 1987:79).
} 
Ne samo u Argentini nego i u Čileu, u Punta Arenasu i Antofagasti, iseljenici su pozvani oglasom da se u što kraćem roku prijave konzulatima i vrate u domovinu kako bi stupili u rat. Iseljenici u Čileu burno su reagirali i odgovorili proglasom Javnosti i našoj slavenskoj braći. Značajan dio iseljenika u Čileu osudio je poziv Austrije u rat protiv Srbije smatrajući ga osobnom uvredom i sramotom. U proglasu su izrazili političku neposlušnost prema austrougarskom konzulu i Monarhiji. Na kraju su proglasa zaključili: ... prošlo je doba prevara [...] austrijska vlada je krvnik naše braće i naših sloboda (Arhiv JNO-a, originalni dokument objavljen u: Antić 1987:50).

Sličan stav pronalazimo i u članku pod nazivom Austrija-Srbi-Hrvati izdanom u iseljeničkom listu Pokret:

Nijesmo obavezni da za obranu Austrije navaljujemo na našu braću i time da počinjamo najgroznijih od ljudskih zločinstava: bratoubojstvo [...] Proti svojoj braći Srbima Hrvati ne smiju da se bore, jer im to brane njihove presvete krvne sveze. Sinovi su obojica jedne jedine majke, jednog jedinog naroda (Pokret, 20. studenoga 1914.).

Kod jugoslavenski opredijeljenih iseljenika prevladavao je stav kako je nacionalno oslobođenje Hrvatske moguće jedino zajedničkom borbom sa Srbijom, a krajnji je cilj razbijanje Monarhije. U tom je kontekstu srpski i hrvatski narod izjednačen - sinovi jedne majke i jednog naroda, kojeg vežu krvne veze. Iz primjera je vidljivo koliko je nacionalizmu metafora porodice neophodna. Nacija se stoga prikazuje kao jedna velika porodica, a njezini pripadnici kao braća (Smith 1998). Druga manjinska grupa iseljenika u Čileu (većinom na jugu Čilea u Punta Arenasu), slično kao u Argentini, isticala je nepremostive razlike između hrvatskog i srpskog naroda, a samim time i nemogućnost da kao takvi utemelje zajedničku državu. Iako nedostaju izvori koji bi nam potkrijepili takve stavove, indirektno to možemo iščitati iz jugoslavenski orijentiranih novina (Pokret, Antofagasta, Čile):

Oni koji pod krinkom zloporabljenog Hrvatstva tendenciozno raspiruju mržnju među braćom, navađajući kao razlog, da Srbi kane nama oduzeti našu djedovinu [...] Znamo da ovdje ima onih koji za da raspiru što veću mržnju između braće, viču i kalabuče, da Velika Srpska propaganda teži da izbriše Hrvatstvo iz povijesti i da ih svih pretvori u Srbe (Pokret, 20. studenoga 1914). 
Jugoslavenski orijentirani iseljenici stoga predlažu određene mjere izgona "nepoželjnih" Hrvata (na strani Austrije) iz iseljeničke zajednice o čemu nam govore apeli koji su tiskani u svakom broju iseljeničkih novina.

Braćo molim vas da upamtite ime i prezime svakog onoga koji danas psuje Slavenstvo, a hvali Austriju, ili se je prijavio da će poći u rat u Austriju. Molim vas učinite to: trebat će nam poslije rata kada će doći do čišćenja naše domovine Hrvatske (Apeli u listu Pokret).

\section{NEUTRALNOST ČILEANSKE IARGENTINSKE REPUBLIKE ZA VRIJEME RATA: RACIONALNI ILI SLOBODNI IZBOR ETNIČNOSTI / NACIONALNOG IDENTITETA HRVATSKIH ISELJENIKA}

Za vrijeme Prvoga svjetskog rata Čile i Argentina imali su status neutralnih država i stoga nisu bili uključeni u ratna zbivanja. Ove okolnosti pomogle su iseljenicima u odlukama: Kojoj će se strani prikloniti u ratu? Kakav će stav zauzeti? Za razliku od Hrvata u domovini koji su kao državljani Austro-Ugarske Monarhije automatski mobilizirani u vojsku za njezinu obranu ili pak Hrvata koji su morali otići u emigraciju radi političke aktivnosti u korist buduće južnoslavenske države, iseljenici su bili u kategoriji Hrvata s mogućnošću slobodnog izbora. Mogli su otkazati poslušnost službenim predstavnicima - austrougarskim konzulatima, a time i vlasti u domovini, povezati se s političkim istomišljenicima i politički se aktivirati.

Bez obzira na status državne neutralnosti, ekonomsku moć u Čileu i Argentini imale su savezničke kolonije ili kolonije sastavljene od pripadnika savezničkih naroda. Zbog kapitalnog ulaganja, a time ekonomske i političke moći engleskih, francuskih i talijanskih iseljenika (Saveznika) u Čileu i Argentini, te pojedinih njihovih zajedničkih poslova/ulaganja s hrvatskim iseljenicima, ta se slobodna odluka našla u raskoraku s pragmatičnim ciljevima. Naime, iseljenici s austrougarskim državljanstvom (AustroUgarska je bila na strani Centralnih sila), automatski su se našli na crnoj listi nepoželjnih iseljeničkih kolonija.

Tu su listu prvo uspostavili Englezi u vidu zabrana ulaska i korištenja engleskih brodova: "Ako je čovjek bolestan te hoće da parobrodom otputuje npr. liječniku, ne može jer kao austrijski podanik ne smije da stupi na 
engleski brod" (Pismo Mičića JO-u, Buenos Aires, 23. listopada 1915.; u cijelosti objavljeno u: Antić 1987:132).

Englezima su se potom pridružili i Talijani koji su proglasili trgovačkoekonomski bojkot. Zbog navedenih razloga hrvatski su se iseljenici počeli odricati austrougarskog državljanstva obraćajući se ruskim poslanstvima, a malo zatim i srpskim konzulatima. O tome nam govori i sljedeći citat:

Gospodin Kebelić se istako za vrijeme svjetskoga rata kao predsjednik društva Kosovo ogranka JNO pomagajući našem narodu koji nije onda mogao dobiti radnje u ničijem poduzeću zbog svojih austrijskih dokumenata, jer kao pripadnici Austrije bili su potjerani svi sa radnja [...] Da se tome doskoči i dođe u pomoć našem narodu sa njegovim su posredovanjem mnogi naši ljudi dobivali srpske iskaznice od srpskog konzulata u Valparaisu gospodina Mitrovića s kojima su bili primljeni i opet na radnju bez ikakvih zapreka jer je s tima iskaznicama bilo dokazano da više ne priznavaju austrijsku vlast (Iseljenik, 15. travnja 1925.).

Delegat JO-a za Južnu Ameriku Mičić permanentno je korespondirao s JO-om raspravljajući o problemu otpuštanja hrvatskih iseljenika (Austrijaka) tražeći hitne postupke kako bi se spasili hrvatski iseljenici koji su otvoreno istupili protiv Monarhije i stoga ostali bez ikakve zaštite u iseljeništvu. Naglašavao je kako bi konkretna mjera JO-a podigla njihov ugled u iseljeništvu. S vremenom se Jugoslavenska narodna obrana (JNO; politički pokret i organizacija u iseljeništvu, o kojoj će poslije biti više riječi) afirmirala kao saveznička ustanova, pa su njezini članovi bili zaštićeni od crne liste savezničkih iseljeničkih kolonija. Dio hrvatskih iseljenika preuzima srpsko državljanstvo. ${ }^{10}$

\footnotetext{
${ }^{10}$ Tzv. Bugaraši ili aristokrati, većinom bogati članovi zajednice iz Antofagaste u Čileu, neki od njih i bivši austrijski konzuli koji su sebe smatrali kremom društva i pričali isključivo kastiljski, ne "miješajući” se s narodom (ostatkom iseljeničke zajednice), istupali su iz redova JNO-a i, kako bi zaštitili ekonomske interese, primali srpsko državljanstvo (iz pisma Milostislava Bartulice Ljubi Jovanoviću, tadašnjem ministru vanjskih poslova Kraljevine Srbije; Arhiv JNO-a, dokument objavljen u: Antić 1987:139).
} 


\section{JUGOSLAVENSKI ODBOR I ISELJENIŠTVO: POVEZIVANJE I USPOSTAVLJANJE KOMUNIKACIJSKIH VEZA U SVRHU LEGITIMITETA I NOVČANE POMOĆI}

Prvo službeno obraćanje JO-a iseljenicima u Južnoj Americi bilo je pismo upućeno Pasku Baburizzi ${ }^{11}$ u veljači 1915. godine zato što je imao važan položaj i velik utjecaj na iseljeničku zajednicu. U pismu se apelira na njegov patriotizam: "Veleštovani gospodine i brate poznavajući Vaše rodoljubne osjećaje [...] poznati patriotizam [...] da priložite vaš obol za prijeke potrebe naše majke otadžbine" (Arhiv JNO-a, dokument objavljen u: Antić 1987:79). Na istu adresu poslan je i proglas Mila braća Jugoslaveni: Srbi, Hrvati i Slovenci izvan domovine (objavljen u cijelosti u iseljeničkom listu Pokret 21. ožujka 1915.).

Cilj mu je obavijestiti iseljeništvo o događajima u domovini, nastalim usred ratnih zbivanja, usporedno osvješćujući njihov nacionalni identitet ili barem elemente nacionalnog identiteta na osnovi kojih će identitet biti ponovno izgrađen.

Prvo na što se u proglasu iseljenici upozoravaju jest razlika između NAS - MI (jugoslavenskih naroda - Hrvata, Srba i Slovenaca) i NJIH - ONI (Monarhije - Nijemaca i Mađara). NAŠE (teritorijalno), to su jugoslavenske zemlje i slobodne kraljevine Srbija i Crna Gora. MI je u poziciji krajnje inferiornog položaja - uključujući sve klase: seljaci (prognani), intelektualci (pohapšeni ili emigrirali), vojska (zavedena u rat protiv rođene braće). ONI imaju moć (Monarhija) i žele iskorijeniti NAS (južne Slavene) tako da nas otjeraju i izbrišu naš jezik. ONI su ciljano držali NAS u ekonomski podređenom položaju.

${ }^{11}$ Pasko Baburizza rođen je 28. travnja 1875. u Koločepu kraj Dubrovnika. Sa 17 godina, 1892., došao je u Čile (Iquique). Prvi posao koji je dobio u Iquiqueu bio je u željezariji kod Nicolasa Gjika, a potom se zapošljava u trgovini mješovite robe kod zemljaka Stančića i Dobroevića. Upoznaje zemljaka Remigia Gazzarija iz Šibenika koji je mesom opskrbljivao jedrenjake koji su dolazili u Iquique po salitru, te postaje njegov ortak prvi put ulazeći u ozbiljniji posao. Od 1895. do 1899. godine živi u Tocopilli nastavljajući trgovati stokom i mesom. Najveći pak uspjeh postiže u salitrenoj industriji u koju ulazi 1904. zajedno s Gazzarijem i Sargom. Godine 1913. udružuje se s Čileancom inženjerom Augustom Brunom i Josipom Lukinovićem te zajedno s njima osniva tvrtku Baburizza, Bruna y Cia. za opskrbu rudarskih i salitrenih tvrtki u provincijama Tarapaci i Antofagasti (Perić 2005). 
Stoga se Monarhija - ONI, odnosno Nijemci i Mađari, opisuju sljedećim riječima: zakleti neprijatelji, dušmani-gospodari, bezdušni silnici, prokleto im ime. Nadalje se ističe nepremostiva razlika između NAS i NJIH. Najveća snaga koja učvršćuje MI jest inferiorni položaj i osjećaj zajedničke ugroženosti, nametnuti odnos vlasti jednog naroda naprama drugomu.

JO je računao na novčanu pomoć iseljenika predstavljajući se kao nadzajednica/nadcentar koji okuplja cijelu naciju: onih koji su ostali u domovini - koji su uhapšeni u domovini zajedno s njihovim obiteljima, zatim onih u emigraciji koji su pobjegli bez novca, a politički su aktivni, te iseljenika koji će novčanom pomoći doći u kontakt (imaginarni i stvarni) sa svim podskupinama i predstavnicima svoga naroda. Novčana pomoć koju je tražio JO od iseljenika izjednačena je sa svetom dužnošću, moralnim i socijalnim činom u ime najveće vrijednosti jednog naroda - slobode domovini i narodu u domovini i iseljeništvu, te konačno povratku iseljenika domovini (u drugom statusu) kao slobodnih građana. Iseljenicima je time dodijeljena važna uloga, ali i odgovornost u stvaranju buduće države. JO se pokušava približiti iseljenicima suosjećajući s njihovom sudbinom u iseljeništvu i osuđujući politiku austrougarskih konzula koja se, prema njihovim riječima, nimalo ne razlikuje od politike Monarhije u domovini, i koja ima jedini cilj razdijeliti narodno jedinstvo. Stoga je, kako su istaknuli, vrijeme ujedinjenja triju naroda koji će zajedničkim snagama istupiti iz Monarhije.

Nakon ove prve faze - pisane komunikacije - JO stupa u drugu aktivnu fazu političke strategije prema iseljenicima: $u$ svrhu propagande $i$ legitimacije upućuje u Južnu Ameriku delegata Miću Mičića, dok je drugi delegat Milan Marjanović upućen u Sjevernu Ameriku.

Osim JO-a, djelovala je i Jugoslavenska ujedinjena omladina ${ }^{12}$ koja je u početku djelovala u redovima $\mathrm{JO}-\mathrm{a}$, a poslije se $\mathrm{u}$ Ženevi ${ }^{13}$ organizirala

\footnotetext{
12 Prema Ljubi Leontiću, na Vidovdanskom kongresu u Beču 1914. godine ilegalno je konstruirana omladinska organizacija JUO koja je zauzela stajališta da je na Balkanu potrebna jaka centralna država, i da bi to trebala biti Srbija s Bosnom, Hercegovinom, Vojvodinom, Dalmacijom, Hrvatskom, Istrom i Slovenijom, te da bi ta država čuvala ravnotežu na Jadranskom moru (original objavljen u: Antić 1987:101). Među omladincima su vodeći članovi bili Oskar Tartaglia i Vladimir Čerina. Sastavljeni su pretežno od dalmatinskih mladića. U Zagrebu pokreću list Vihor, a u Pragu Jugoslaviju.

${ }^{13}$ U Ženevi su prvo na sastanku 18. travnja 1916. diskutirali omladinci o organizaciji jugoslavenske nacionalističke omladine koja bi javno istupila kao nezavisna, organizirana
} 
samostalno. Omladinci su bili uglavnom revolucionari i članovi Srpske narodne obrane, a kojoj je cilj bio osnivanje jedinstvene centralističke Jugoslavije. ${ }^{14}$ Ženevska omladina prva je uspostavila veze s Južnom Amerikom. ${ }^{15} \mathrm{U}$ lipnju 1915. godine JO je donio odluku na osnovi koje je Mićo Mičićc ${ }^{16}$ kao njezin službeni delegat otputovao među iseljenike u svrhu mobiliziranja pojedinaca i jačanja iseljeničkog pokreta. Iako je došao pod krinkom organiziranja dobrovoljačkih skupina, stvarni cilj njegova dolaska bio je ispitati financijsku moć iseljenika. Najmoćniji (ekonomski) i najutjecajniji čovjek među iseljeništvom u Argentini bio je Nikola Mihanović, ${ }^{17}$ te mu Mičić u komunikaciji s JO-om posvećuje

cjelina za ostvarenje jugoslavenskoga nacionalnog programa kao samostalnog tijela. Na sastanku 2. svibnja 1916. godine mladići Bartulica, Latas i Fabijančić sklopili su sporazum o zajedničkoj radikalnoj akciji u ime Jugoslavenske nacionalističke omladine, s ciljem da organizirano i samostalno istupi kao treći faktor pored JO-a i Srpske vlade za ostvarivanje jugoslavenskoga nacionalnog programa (u svrhu programa će izdavati list, brošure, proglase, okupiti oko Centralnog odbora sve pojedince koji su imali učešća u radu jugoslavenske nacionalističke omladine prije i za vrijeme rata; Bartulica se obvezuje da će angažirati iseljenike u Americi da ih moralno i materijalno podrže, dok će Fabijančić na sebe preuzeti organiziranje rada za Europu) (izvor u originalu objavljen u: Antić 1987:103-106). U Ženevi su najaktivniji bili dr. Ljubo Leontić, bivši urednik Jugoslavije, prvoga zajedničkog organa cjelokupne nacionalističke omladine u Monarhiji koji je 1914. godine izlazio u Pragu. U proljeće 1915. izdaju knjižicu La Unite Yugoslave: "Pošto su Srbi, Hrvati i Slovenci jedan jugoslavenski narod oni će poslije oslobođenja biti ujedinjeni u jednu homogenu državu. Srbiji, Pijemontu Jugoslavenstva, imat će se prikloniti ostale zemlje srpske, hrvatske i slovenačke" (Paulova 1924:96).

${ }^{14}$ Bila je bliža Pašalićevoj koncepciji nego Supilovoj jer je smatrala kako će Srbija osloboditi hrvatske i slovenske zemlje te kako će njezinom zaslugom doći do ujedinjenja jugoslavenskih naroda.

${ }^{15}$ Dr. Ljubo Leontić već je u Čileu bio poznat kao urednik Jugoslavije koju su čitali mlađi iseljenici. Osim toga, Leontić je imao utjecaj i na brata koji je živio u Čileu. Preko njega se proširio utjecaj i na mlade iseljenike / potomke iseljenika: pretpostavljamo kako je njihova komunikacija mnogo doprinijela razvoju "jugoslavenskog pitanja" u iseljeništvu.

${ }^{16}$ Miče Mičić, Dubrovčanin, bio je izaslanik JO-a u Južnoj Americi. Stigao je u Buenos Aires 2. rujna 1915. godine u cilju organiziranja iseljenika: "Dr. Mičić će pomoću naših tamošnjih rodoljuba organizovati niz predavanja o našim problemima i nastojat će da udari temelj što boljoj opće-narodnoj organizaciji naše prekomorske braće, koja će u narodnogospodarskim pitanjima naše buduće slobodne domovine igrati znatnu ulogu" (Arhiv JNO-a, knj. 1, 5. srpnja 1934.).

${ }^{17}$ Nikola Mihanović rođen je 21. siječnja 1848. godine u selu Doli kod Dubrovnika. Prije negoli je navršio 13 godina, ukrcao se na mali brod kao član posade i plovio po 
posebnu pozornost. Unatoč svim pokušajima zbližavanja i pridobivanja za jugoslavenski pokret, Mihanović je tijekom cijelog rata ostao na strani Monarhije.

U Čile je na poziv omladinaca iz Antofagaste došao predstavnik JUO-a Ljubo Leontić. ${ }^{18}$ U usputnim lukama u Punta Arenasu i Valparaísu održavao je predavanja naglašavajući značaj i važnosti formiranja dobrovoljačkih

jadranskim i mediteranskim lukama. Godine 1867. iskrcao se s engleskog broda u Urugvaj (Montevideo) i pošao je u Paragvaj. Kako su u to vrijeme Argentina, Brazil i Urugvaj vodili rat protiv Paragvaja, slobodna je bila plovidba po rijeci Parani, a brodovi su prevozili na osnovi ugovora. Vidjevši u tome dobar posao, naselio se u Alto Parani i putem takvih ugovora prevozio robu i ratni materijal. Kad je zaradio novac, odlučio se vratiti u domovinu, ali ga slučajno u gostionici Adriatico u Buenos Airesu zemljaci nagovore da ostane. Tako je 1868. godine ostao u Buenos Airesu. Prvo je radio na brodu Talijana Juana Bautista Lavarella s kojim postaje prijatelj, a poslije i poslovni partner. Godine 1875. postaje mali brodovlasnik kada je kupio tri broda: Buenos Aires, Kate i Jeny. Nakon iznenadne smrti poslovnog partnera Juana, nastavlja posao sam i ženi se njegovom udovicom. U međuvremenu za partnere uzima Jerka Zdanića i Oktaviana Kozulića i kupuje četiri broda. Društvo je vođeno pod imenom Mihanović \& Cia do 1888. kada je isplatio svoje partnere, a poduzeću dao ime Nicolas Mihanovich. Sudjelovao je i u prevoženju materijala za željezničku prugu prema Bahía Blanci i prijevozu poljoprivrednih proizvoda i stoke u Buenos Aires. Pojačava svoju flotu kupnjom novih brodova (dva broda naziva imenom Dalmacia i Austria). Prvi je uspostavio putnički promet između Buenos Airesa i gradova Colonije i Carmela u Urugvaju. Godine 1909. Mihanović postaje "apsolutni gospodar argentinske trgovačke mornarice" raspolažući sa 68 tegljača, 200 manjih brodova, 82 broda na paru - ukupno njih 350. Osnovao je i niz poduzeća koja nisu imala veze s pomorstvom. Bio je član raznih humanitarnih i bankarskih udruženja u Argentini i Europi. Pomagao je i hrvatske kolonije u Argentini. Franjo Josip imenovao ga je počasnim konzulom s titulom baruna s pravom nasljedstva. Posjedovao je visoka odlikovanja ruskog cara te engleskog i španjolskog kralja (Rojnica 1974:171-176).

${ }^{18}$ Leontić je otputovao u Južnu Ameriku (Čile) na poziv omladinaca iz Antofagaste s kojima je kao predstavnik JUO-a bio u kontaktu prije rata. Odnosi Leontića i omladine naspram JO-a bili su napeti. Naime, omladinci su bili radikalniji i bez ikakve rezerve prema srpskoj vladi i uređenju buduće države smatrajući kako će ratom nestati bilo kakvi međunacionalni odnosi, dok je JO bio oprezniji i smatrao kako će o načinu stvaranja buduće države ovisiti njezino unutrašnje uređenje (usporedi: Antić 1987:86). Nakon organiziranja i sakupljanja dobrovoljaca iz Južne Amerike za frontu, Mičić je čekao trenutak da JO potvrdi odluku i djelovao prema instrukcijama JO-a, dok je Leontić bio neovisan, popularan kod mlađih iseljenika i bio je za odlazak dobrovoljaca pod svaku cijenu. Kad je stigla odluka JO-a da se dobrovoljci ipak zadrže, došao je u pitanje i cijeli jugoslavenski pokret. 
jedinica u iseljeništvu. Njegov zadatak u Južnoj Americi bio je "agitacija za sakupljanje dobrovoljaca, stvaranje jedinstvene iseljeničke organizacije i organiziranje tiska" (Leontić 1961:128-129). Njegov dolazak ${ }^{19}$ imao je snažan utjecaj na razvoj iseljeničkog pokreta u Čileu. Odnosi između Mičića kao službenog predstavnika JO-a i Leontića kao člana JUO-a ${ }^{20}$ od samog su početka bili napeti zbog drugačijeg poimanja i pristupa ratnim akcijama, srpskoj vladi i budućem uređenju države. Takva različitost bit će prenesena u sam iseljenički pokret unutar kojeg će se formirati dvije političke grupe iseljenika: konzervativna i radikalna.

$\mathrm{Na}$ iseljeničkom Zboru održanom 1. kolovoza 1915. godine u Antofagasti iseljenici su službeno priznali legitimitet JO-a smatrajući ga svojim jedinim narodnim i domovinskim predstavnikom:

... svi Jugoslaveni nastanjeni na Pacifiku odlučno svoj glas dignu u obrani svetinja, kao što istodobno da iskažu potpuno povjerenje našim jedinim predstavnicima JO u Londonu, koji predstavlja čiste narodne jugoslavenske aspiracije [...] Jednom kad naša braća u Domovini ne mogu, pozvani smo mi Jugoslaveni, koji živimo u ovim slobodnim zemljama, da im podamo odlučno i neograničeno povjerenje za njihov rad, te da javno čitavom kulturnom svijetu iskažemo da smo za naša narodna prava spravni na sve žrtve. (Jugoslavija, 24. srpnja 1915.)

JNO u Južnoj Americi odlučio je snositi sav financijski trošak opstanka i rada JO-a u Londonu, a o toj su odluci obavijestili JO u prosincu 1916. godine.

\footnotetext{
${ }^{19}$ Došao je prvo u Punta Arenas u rujnu 1915. godine. U knjizi piše da je njegov zadatak u Južnoj Americi bio agitacija za sakupljanje dobrovoljaca, stvaranje jedinstvene iseljeničke organizacije i organiziranje tiska koji bi trebao odigrati osobitu ulogu prilikom sklapanja primirja (Leontić 1961:128-129).

${ }^{20}$ Organizacija je ilegalno osnovana na kongresu u Beču 1914. Bila je riječ o organizaciji nacionalističke omladine, borbeno usmjerene, koja nakon izbijanja rata više nije mogla djelovati u domovini. Mladi su poticali osnutak Jugoslavenskog odbora i dobrovoljačkih grupa nazvanih Jadranska legija, a poslije Jugoslavenskih dobrovoljaca u čije su se redove i sami uvrstili. Oni su u početku zamjerali Trumbiću što odugovlači s osnivanjem Odbora, znajući za diplomatske namjere Italije i upućivanje dobrovoljaca na bojište (Machiedo Mladinić 2007:40).
} 


\section{ISELJENIČKI POKRET JUGOSLAVENSKA NARODNA OBRANA (JNO): POLITIČKO ORGANIZIRANJE ISELJENIKA}

Početne radnje oko šireg organiziranja iseljenika u Čileu i Argentini svodile su se na samoinicijativno organiziranje iseljenika unutar iseljeničkih društava u cilju prikupljanja novčane pomoći Crvenom križu Srbije i Crne Gore (od one grupe iseljenika koja se priklonila jugoslavenskoj nacionalističkoj koncepciji stvaranja buduće države). Na jugu Čilea u Punta Arenasu zbog objave i početka rata sazvan je skup 27. kolovoza 1914. pod nazivom Skup Crvenog križa i siročadi domovine koji je organiziralo Hrvatsko pripomoćno društvo.

Potom u drugoj fazi nastupa razdoblje djelovanja JO-a i JUO-a, kad njihovi izaslanici dolaze u Argentinu i Čile u cilju organiziranja dobrovoljačkih grupa koje bi se borile u srpskoj vojsci na strani Srbije protiv Monarhije (Perić Kaselj 2014). Tako je nacionalna definicija nametnuta izvana iako je dio iseljenika već bio nacionalno (za južnoslavensku koncepciju) opredijeljen, ali bez šire integrativne političke organizacije. Posebnu poziciju zauzimao je mlađi naraštaj Hrvata u Čileu u Antofagasti koji su bili u kontaktu s revolucionarnom omladinom u domovini prije rata i koji su izražavali solidarnost i simpatije prema Srbima i Crnogorcima od Balkanskih ratova. Stoga je ideja oko organiziranja jugoslavenskoga iseljeničkog pokreta (JNO-a) odmah prihvaćena među dijelom iseljeništva u Antofagasti, mjestu koje postaje centar iseljeničke akcije.

U Antofagasti je 14. veljače 1915. sazvan prvi iseljenički Zbor na kojem je izabrana Privremena uprava JNO-a koja je definirala buduće zadatke: izraditi program organizacije, osnovati službene novine/glasilo organizacije, i zajedno s JO-om ujediniti Slavene u zajedničkoj borbi protiv Monarhije. Na iseljeničkoj skupštini (iseljenici su je nazvali skupštinom ujedinjenja JNO-a na južnom Pacifiku) 2. svibnja 1915. godine u Antofagasti u dvorani Slavjanskoga pripomoćnog društva dan je program JNO-a na usvajanje. Tom je prilikom iznesena njezina svrha i cilj:

Ona je pozvana da nas pred čitavim javnim mnijenjem, pred svim narodnostima pokaže kao narod koji je na visini XX vijeka, te da u svakom potrebnom času domovini pruži pomoć, dostojno i obilato. JNO je pozvana da onim tiranskim i krvoločnim vladama - pod kojima se na nesreću naši rodili - kažemo glasno i jasno, da nijesmo nikakvi robovi, da nismo nikakva nesvjesna topovska hrana. Da 
nijesmo nikakvo podlo sredstvo s kojim oni svoje ambiciozne i proždrljive nagone mogu da utaže i nasite, te da smo spravni da se latimo i najskrajnijih sredstava, da prokleti, sramotni žig robije sa čela odstranimo. (Jugoslavija, 20. svibnja 1915.)

Na skupštini su zatim prihvaćeni "glavni uvjeti za oživotvorenje JNO” i osnovan je prvi ogranak JNO-a Jadran:

Kao međ ostalim tako i među nama počela se je da budi svijest, oćutio se je nagon samoodržanja, te smo uvidjeli, da i mi kao jedan dio Jugoslavije moramo da se trgnemo i žilavo se prihvatimo rada [...] Potrebe domovine, u ovim časovima su tako ogromne, da jedino jedna kolektivna akcija da urodi nekakvim plodom. Kako jedino se moglo doći do cilja, ako ne sa jednom zamašnom organizacijom koja bi nas sve pokupila pod jednu te istu zastavu ... (Jugoslavija, 20. svibnja 1915.)

Na Kongresu održanom 23. siječnja 1916. u Antofagasti glasovanjem su usvojeni politički i radni program te ustav i pravila JNO-a. Na kongresu je donesen i politički program koji je sačinjavala Misao vodilja:

Srbi, Hrvati, Slovenci, zajedničkim imenom Jugoslaveni, jedan su narod. Radi toga, oni traže oslobođenje svih Jugoslovena i ujedinjenje svih jugoslovenskih zemalja u jednu, jedinstvenu, slobodnu narodnu državu. [...] Srbija je nosiocem Jugoslavenske Misli. Ona je osnovica i srce Jugoslavenske Države [...] Jugoslavenske zemlje jesu: Srbija, Crna Gora, Hrvatska sa Rijekom, Slavonija, Dalmacija i Istra sa otocima, Bosna, Hercegovina, Trst s okolicom, Gorica, Gradiška, Kranjska, Južna Koruška, Južna Štajerska, Preko i Međumorje, Baranja, Bačka, Banat. Prema tome Jugoslaveni traže oživotvorenje svoje države prema načelu narodnosti. (Jugoslavenska država, 6. veljače 1916.)

Na kongresu je bila utvrđena organizacijska ${ }^{21}$ i financijska struktura ${ }^{22}$ JNO-a. Nakon kongresa, upućen je brzojav srpskom kralju Petru I.:

${ }^{21}$ Ona se sastojala od ogranaka i podružnica. Ogranci su bili osnovne organizacije JNO-a po pojedinim naseljima. Zakonodavno tijelo JNO-a bio je Zbor koji se konstituirao od delegata ogranaka, a sastajao se jednom godišnje. Ogranci su imali unutrašnju autonomiju, ali nisu imali utjecaja na Upravu koja je bila izvršni organ JNO-a. Antofagasta, Punta Arenas i Buenos Aires bili su administrativni centri za ogranke. Senat je činio nadzorno vijeće JNO-a koji se sastojao od članova Uprave JNO-a te drugih članova koje 
Jugoslaveni iz neoslobođenih zemalja, nastanjeni u Republikama Čile, Argentina, Bolivija i Peru okupljeni na zboru u Antofagasti 23. 1. 1916. prekinuvši sve veze s Austro-Ugarskom i vezavši svoju sudbinu sa onom Srbije, za sva vremena i sve prilike, pozdravljaju oduševljeno svoga Kralja i svoju Vladu stavljajući im na raspolaganje svoje imetke i živote. (Jugoslavenska država, 6. veljače 1916.)

\section{PODRŠKA JUGOSLAVENSKOM ISELJENIČKOM POKRETU U ČILEU I SUZDRŽANOST U ARGENTINI}

Gotovo sva iseljenička društva u Čileu i Argentini transformirala su se u ogranke JNO-a. Usporedno su s njima djelovala i društva koja se nisu htjela opredijeliti za južnoslavensku koncepciju (npr. Dalmatinsko društvo u Punta Arenasu, Hrvatski savez u Rosariju i dr). U pokret su se uključile i žene - iseljenice, najavljujući svoju aktivnu ulogu u budućim zbivanjima u domovini. Ženski ogranci JNO-a bili su Katarina Zrinska u Punta Arenasu i Kosovka djevojka u Antofagasti.

Jugoslavenski narodni pokret izazvao je velike simpatije i podršku Čileanaca o čemu nam govore i sljedeći primjeri:

Sa Čileom smo povezani prijateljski jer je za vrijeme rata pružila našim zemljacima bratsko gostoprimstvo i pokazala puno shvaćanje za političke težnje Jugoslavena prateći sa simpatijama naš pokret. (Novi iseljenik, 3. svibnja 1929.)

Od čitave emigracije ona u Čileu je najvrjednija i najpoduzetnija i po nacionalnoj svijesti. Na to je utjecao povoljan ambijent u Čileu gdje su naučili što je sloboda. Podupirali su odbor u Londonu i Srpski Crveni krst. Pokret je uživao stalne simpatije Čileanaca i potpunu

je imenovao Zbor. Članovi Senata birali su se na doživotno. Senatorima su bili imenovani najimućniji i najugledniji članovi JNO-a. Autonomiju ogranaka osiguravala je Skupština kao zakonodavno tijelo odnosno odbori kao izvršno tijelo. Autoritet nad ograncima imala je jedino središnja Uprava JNO-a, a ne uprava ogranaka. Službeni jezik u JNO-u bio je jedan od južnoslavenskih narječja (hrvatski, srpski) (podatke iznosimo prema: Antić 1987.; Jugoslavenski glasnik, 1945.-1947., Arhiv JNO-a).

${ }^{22}$ Reguliranje novčanih odnosa članova i ogranaka JNO-a, ogranaka i Uprave JNO-a te JNO-a i Jugoslavenskog odbora. Prema svojim statutima i financijskoj osnovi, JNO je na sebe preuzeo cjelokupno financiranje rada Jugoslavenskog odbora (prema dokumentima iz Arhiva JNO-a). 
slobodu pod zaštitom čileanske zastave. Čileanska štampa je stajala na raspolaganju našem pokretu i pratila borbu za naše oslobođenje. Čileanski narod učestvovao je u gotovo svim našim akcijama. Sa posebnom zahvalnošću trebaju dati tom gostoljubivom narodu kojima je bila prava domovina dok smo čamili u ropstvu. (Jorge Matulović, Novi iseljenik, 18. rujna 1929.).

S ekonomskog gledišta, čileansko gospodarstvo se u razdoblju rata još više razvijalo jer su u ratu potrebe za nitratom bile povećane posebno u industriji oružja i izradi eksploziva. Hrvatski iseljenici - gospodarstvenici još su povećavali svoj kapital, a time i ekonomski utjecaj što je na kraju rezultiralo i osnivanjem Jugoslavenske banke u Punta Arenasu s predsjednikom Paskom Baburizzom. Osnovane su podružnice u Valparaísu i Antofagasti. Bila je to prva ekonomska institucija s jugoslavenskim nazivom. Banka je doprinijela jačem gospodarskom napretku iseljenika i postala je osnova njihova ekonomskog života u trgovini i industriji. S druge strane, ona ih je predstavljala i u Čileu kao ekonomski utjecajnu useljeničku zajednicu, u rangu s najutjecajnijim iseljeničkim kolonijama, kao npr. Englezima.

Za razliku od Čilea, iseljenički pokret u Argentini veoma je sporo napredovao. O tome piše i iseljenički list Jugoslavija: “... u Argentini naša nacionalna borba oštećena gore nego igdje [...] sve moguće zapreke koje se mogu da zamisle, priječe širenje naše narodne misli" (Jugoslavija, 19. siječnja 1916.). Među inim razlozima spominjalo se i stalno odgađanje društva Jadran da pristupi iseljeničkom pokretu. Društvo će nakon duljeg čekanja pristupiti pokretu i postati ogranak JNO-a istog imena. Budući da se ogranak nije osobito razvijao, niti je imao značajan utjecaj među iseljenicima, članovi uprave Jadrana pozvali su Leontića ${ }^{23}$ na pomoć riječima: "Mi ovdje nemamo ljudi sposobnih za to" (Pismo Markovića Leontiću, Buenos Aires, 20. svibnja 1916., u: Antić 1987:153). Leontić, nakon što je proveo snažnu organizaciju na tihooceanskoj obali Južne

${ }^{23}$ Sam je Leontić istaknuo da je dugim radom, dopisivanjem i traženjem podataka o jugoslavenskim kolonijama, posjećivanjima, razgovorima s pojedincima, predavanjima $i$ sastancima osnovao, pod stalnim nadzorom, tri centra JNO-a - Antofagasta, Punta Arenas i Buenos Aires - i skoro sve ogranke (Usp. Leontić 1961). 
Amerike (poglavito Čilea), stigao je u Argentinu, točnije u Buenos Aires, s namjerom osnivanja autonomnog centra oko kojeg bi se okupljali ogranci JNO-a po Argentini, Urugvaju ili Brazilu. Taj je centar trebao biti neovisan, a s JNO-om na Pacifiku trebao je imati samo zajedničko ime i program. Uprava JNO-a Pacifik prihvatila je ovaj prijedlog i imenovala ogranak Jadran $^{24}$ Centrom JNO-a za Atlantik (vidi više: Antić 1987:154-155). Nakon formiranja Centra JNO-a u Buenos Airesu, situacija se nije značajno promijenila, a Leontić je ostao do veljače 1917. godine iako nije postigao onakav uspjeh kao što je to bio slučaj s Pacifikom. ${ }^{25}$ Osim Centra Jadran osnovano je niz ogranaka JNO-a na cijelom teritoriju Argentine, ali oni nisu bili brojčano veliki jer je i sam centar u Buenos Airesu bio slab, sklon osipanju članstva i unutarnjim sukobima. ${ }^{26}$ Krajem 1918. godine JNO je u Južnoj Americi imao 65 ogranaka, od kojih je pola bilo u Argentini, a većinom su članovi bili siromašni iseljenici zemljoradnici (tzv. čakareri) (Bartulica, Arhiv JNO-a, knj. 4, sv. 1, 20. ožujka 1935.).

Za razliku od Čilea, situacija u Argentini bila je drugačija o čemu svjedoči Ljubo Leontić: "Postupci tamošnjih vlasti primoravali su me da radim oprezno - izmičući policijskim organima koji su (pod budnom kontrolom Austro-Ugarskom i njemačkog poslanstva i konzulata) strogo čuvali naročito argentinsku neutralnost" (Leontić 1961:95).

Prema ocjeni Leontića, u Argentini je djelovala snažna "austrijska propaganda". Proaustrijski orijentirani iseljenici (protivnici jugoslavenske ideje ujedinjenja, koji su za rješenje hrvatskog pitanja unutar Monarhije) bili su podijeljeni u tri grupe: prva okupljena oko društva Virbusunitis (gdje je bilo nešto hrvatskih iseljenika), druga grupa u Acebalu organizirana u društvu Franjo Josip $I .{ }^{27}$ pod vodstvom Drinkovića, te grupa oko

${ }^{24}$ Leontić je osnovao ovaj centar zbog slabih kontakata i nepovjerenja između vodstva JNO-a Buenos Aires i JNO-a Valparaíso.

${ }^{25}$ U izvještaju Centra Jadran za godinu 1916./17. Upravi u Valparaísu navodi se da je ogranak u teškom položaju zbog malodušnosti i siromaštva jugoslavenske kolonije i da ogranak broji svega 400 članova, koliko imaju i svi ostali koji spadaju pod Centar JNO-a Jadran (Jadran, 3. studenoga 1917.).

${ }^{26}$ Primjeri pokazuju kako je dio Hrvata članova JNO-a vidio opasnost za svoj nacionalni identitet jer su njihova "braća" Srbi nerado pristupali u ogranke JNO-a. Članovi srpske nacionalnosti izašli su iz ogranka Jadran i osnivali vlastito društvo Srbija.

${ }^{27} \mathrm{Ne}$ čini nam se logičnim da su se braća Drinkovići (utjecajni trgovci sa zavidnom ekonomskom moći i utjecajem) bili okupljali u društvu Franjo Josip I. jer je društvo 
Radeljaka u Hrvatskom savezu (Leontić 1961:95). Smatrao je kako su grupe međusobno razjedinjene te kako postoji mogućnost da se druga i treća grupa pridobiju za pokret. O iseljenicima zemljoradnicima kod kojih nije bio osobito popularan niti razvijen iseljenički pokret, Leontić zaključuje:

Sva politika naših chacarerosa sastoji se $u$ tome da ne izgube kod kuće dva pedlja zemlje i da mu - svojtu ne objese [...] Uopće, pismena ni usmena propaganda, direktna ili sa razumnim razlozima ne utječe na ove ljude. Oni ne čitaju, oni ne razgovaraju - oni uopće ne vide i ne razumiju položaj, niti na ratištu niti u politici. Inteligentni su vrlo rijetki [...]. Konzulati i Zajednica podržavaju baš te rudimentarne osjećaje, šire strah i nepovjerenje za svaku akciju uopće. (Izvještaj Leontića Upravi JNO-a, original objavljen u: Antić 1987:53)

Delegat JO-a Mičić u svom će izvještaju JO-u također pisati o ovom problemu: "Argentina je livada, dok je Chile već uzorana oranica" (Pismo Mičića JO-u, Buenos Aires, 4. listopada 1915., u: Antić 1987:87).

Paulova (1924:227) ocjenjuje kako je na slabo organiziranje iseljenika u Argentini uvelike utjecao socijalni položaj iseljenika jer je uglavnom bila riječ o ratarskom stanovništvu razasutom po nepreglednim pampama. Antić (1987) smatra kako je hrvatskom zemljoradniku u Argentini bilo svejedno hoće li biti Jugoslaven ili ostati Austrijak, dok su bogati iseljenici u Čileu zbog svoga položaja morali o tome voditi računa.

JNO prestao je s radom u ožujku 1919. godine.

\section{ULOGA ISELJENIČKOG TISKA U OBLIKOVANJU NACIONALNOG IDENTITETA ISELJENIKA}

Iseljenički tisak u Čileu u ovom razdoblju ima značajan utjecaj među iseljeništvom poglavito u formiranju različitih političkih stavova (Perić 2006). Iseljenici u Čileu okupljali su se oko listova Domovina, Pokret i Sloboda. Domovina je propagirala južnoslavenski unitaristički nacionalni

ovakvog imena postojalo početkom stoljeća; naime, to je ime bivšega Austro-ugarskog društva uzajamne pomoći za koje nemamo podatak da je imalo podružnicu u Acebalu. Osim toga, Drinkovići su bili zagovornici hrvatskog pokreta i u članstvu pripomoćnog društva Kralj Tomislav. 
program. Nagađalo se kako je jedan od utjecajnih masona ${ }^{28}$ bio i sam urednik Domovine Luka Bonačić Dorić. Budući da je Domovina širila antiklerikalizam među iseljeništvom, mjesni svećenički list El amigo de la familia iz Punta Arenasa napao je Domovinu kao "list za masonsku propagandu" (Domovina, 25. svibnja 1915.). U studenome 1914. godine izdan je prvi broj novina Pokret u Antofagasti. Osnivač Pokreta bio je iseljenik Matej Škarnić ${ }^{29}$ koji je ujedno posjedovao i vlastitu tiskaru. Prvi je uspostavio vezu s JO-om, a njegove su ambicije išle do toga da se preko novina, utjecajem na javno mnijenje iseljenika, želio nametnuti kao vođa jugoslavenskoga iseljeničkog pokreta. ${ }^{30} \mathrm{JO}$ u Londonu u početku podržava Škarnićev rad, sve do početka 1916. godine kada se priklanja Privremenoj upravi JNO-a. Na ovu odluku JO-a utjecala su pisanja i izvještavanja izaslanika Mičića, ${ }^{31}$ a presudan korak u odluci bilo je obustavljanje novčane pomoći od strane Baburizze i njegove grupe JO-a. ${ }^{32}$ Iako su novine Pokret zastupale i propagirale nacionalnu južnoslavensku koncepciju koja nije bila u suprotnosti nego istovjetna programu iseljeničkog pokreta, Privremena uprava JNO-a nije ih mogla kontrolirati te je stoga odlučila izdavati druge novine. Shodno tomu, 22. travnja 1915. izašao je prvi broj novina Jugoslavija (vidi više: Perić 2006). Urednik je bio Ljubo Leontić..$^{33}$

${ }^{28}$ Među članovima JO-a u Londonu, ali i u pokretu JNO-a u Čileu bilo je članova masonskih loža.

${ }^{29}$ NajprijeježiviouBolivijiizkojejeprotjeranpodoptužnomizdavanja“"slobodnomislilačkih" novina. Nakon progona živi u Antofagasti gdje izdaje masonsku reviju Luz y verdad. Bio je upravitelj Slavjanskoga vatrogasnog društva br. 3 i Slavjanskoga pripomoćnog društva (vidi više: Antić 1987:59).

${ }^{30}$ Škarnić je uspostavio kontakt s JO-om u Londonu preko tajnika Jedlowskoga kojem u povjerljivom pismu navodi najistaknutije osobe u iseljeništvu, kao npr. Bonačića Dorića, Kusanovića, Mora, Žuvića, Roića, Petrinovića, Palaveršića i Lukšića. Od tada Jugoslavenski odbor prihvaća njegovo vodstvo. Preko tajnika prima povjerljiva pisma s instrukcijama za budući rad iseljenika koja prenosi Privremenoj upravi (Antić 1987:59).

${ }^{31}$ Upozoravat će JO da su u Upravi JNO-a najutjecajniji iseljenici te da je Jugoslavija ipak službeno glasilo JNO-a. Nadalje je istaknuo kako je nagovarao Škarnića da se učlani u JNO što je on odmah odbio (vidi više: Antić 1987:59).

${ }^{32}$ Najutjecajniji i najbogatiji iseljenik Baburizza poslao je brzojav u svoje i ime svoje grupe Mitroviću u London da obustavi potporu JO-u. Osim toga, Baburizza nije želio ući u JNO dok JO bude podržavao Pokret (vidi više: Antić 1987:61).

${ }^{33}$ Vođa JNO-a u Antofagasti, jedan od vodećih članova Jugoslavenske ujedinjene omladine. Za vrijeme rata mobiliziran je u vojsku. Dezertira i bježi u Italiju. U Francuskoj 
U uredništvu Jugoslavije nalazili su se imućni iseljenici (vodeći članovi JNO-a).

Iseljenički tisak za vrijeme rata i njegov utjecaj na iseljeničku zajednicu bio je od iznimne važnosti. U Argentini su novine Zajednica, pod uredništvom Radeljaka, imale velik utjecaj na iseljeništvo poglavito onog dijela iseljenika koji nisu bili pristaše južnoslavenske koncepcije buduće države na unitarističkom principu. Stoga ih je i sam Leontić nazivao frankovačkim listom. Neki natpisi iz Domovine pokazuju kako se tijekom rata Zajednica pisanjem približila jugoslavenskom programu, ali ne unitarističkom nego federativnom:

Dakle i mi smo za Jugoslaviju i svom dušom Jugoslaveni, ali prije svega smo Hrvati, kao što su Srbi Srbi itd. I mi smo za Jugoslaviju, ali za Jugoslaviju federativnu, po uzoru sjeverno-američkih sjedinjenih država, tj. za onu i onakvu federaciju jugoslavensku, u kojem će Hrvat biti i ostati Hrvatom, te u svojoj kući, u svom pravu i pod svojim narodnim imenom historičkim zapovijedati, a tako Srb na svom, Bugarin i Slovenac na svom; u tom svojem skupa bratovati pod zajedničkim imenom Jugoslavija i pod tim imenom za vani istupati [...] Ovakvu Jugoslaviju shvaćao je i otac Jugoslavije namrli biskup Josip Juraj Strossmayer kao što shvaćaju i svi pravi Hrvati, Srbi, Bugari i Slovenci. A shvaćaju zato, jer samo ovakva Jugoslavija može biti ostvariva i može biti bratska. (Zajednica, 25. travnja 1917., prenijela Jugoslavenska domovina, 20. svibnja 1917.)

O utjecaju Zajednice među iseljenicima govori i sljedeći prilog u kojem se ogranak JNO-a Banat iz Venado Tuerta žali Upravi JNO-a u Valparaísu:

Ovdje mi imamo veliku borbu, Radeljak ima veliki utisak sa svojom lukavštinom nad ovom kolonijom. Zato tražimo od vas 50 primjeraka Krfske deklaracije 'za propagandu jer naši ljudi misle da ćemo mi Hrvati biti serbski robovi'. (Pismo ogranka JNO-a Banat Upravi JNO-a u Valparaísu, 1. siječnja 1918., u: Antić 1987:153-154)

ulazi u Legiju stranaca zajedno s desetak omladinaca koji zastupaju stav da su Južni Slaveni jedan narod (Antić 1987). 
Novine Sloboda bile su politički kontradiktorne pisanju Zajednice, te su stoga ove dvije iseljeničke novine bile u stalnom sukobu. Novine Sloboda zagovarale su jugoslavenski program, poglavito kad je uredništvo novina preuzela supruga bivšeg urednika Klotida Vuković. Tijekom rata, i u napadima na Zajednicu, svrstale su se na stranu čileanskog lista Domovina. Nasljednik Slobode postao je Jadran. U jesen 1916. godine Ljubo Leontić izdao je bogato opremljen broj Jadrana koji je od tada i službeno glasilo JNO-a u Argentini te jedini list na atlantskoj obali Južne Amerike. Njegov urednik bio je Kalafatović.

\section{TRANSISELJENIČKI PROSTORI: KOMUNIKACIJA, KULTURA, POLITIKA}

Zbog ratnih okolnosti iseljenici u Čileu i Argentini kreiraju specifičan transiseljenički prostor koji se premješta iz prostora društva podrijetla/ domovine u drugi fizički prostor. Komunikacija s domovinom nije prekinuta nego se obavlja na drugačiji način: preko dijela njezinih predstavnika (koji se imenuju Jugoslavenskim odborom) u drugom fizičkom prostoru, izvan teritorija domovine, unutar prostora u kojem se, s obzirom na ciljeve te domovinske grupe, komunikacija nesmetano mogla održavati. Emigriranjem hrvatskih, srpskih i slovenskih pojedinaca (u cilju nastavka borbe započete u domovini oko ujedinjenja i oslobođenja južnoslavenskih zemalja od Monarhije) iz Austro-Ugarske Monarhije i njihovom političkom aktivnosti $\mathrm{u}$ inozemstvu (Londonu) stvoren je novi društveni prostor. Taj prostor karakterizira ujedinjeno djelovanje triju slavenskih naroda Monarhije, intenzivna komunikacija sa srpskom vladom (buduća zajednička država sa Srbijom i Crnom Gorom) te diplomatska komunikacija s predstavnicima savezničkih zemalja, pojedinačna komunikacija s pojedincima iz domovine, pojedincima iz domovine koji su emigrirali u druge europske zemlje te pojedincima iz redova JUO-a. Različiti oblici navedenih skupnih komunikacija prenose se u iseljeništvo - u Čile i Argentinu. Komunikacija $\mathrm{s}$ iseljeništvom uspostavlja se pismenim putem (brzojavima, pismima i izvještajima) i telefonski. Drugi oblik komunikacije uspostavlja se putem službenih izaslanika JO-a ili predstavnika JUO-a u Čileu i Argentini, koji drže predavanja, organiziraju skupove, skupštine, izravno i brzo prenoseći informacije među iseljeništvom o situaciji u domovini, položaju JO-a 
i zajedničkim akcijama JO-a i iseljeništva. Treći oblik komunikacije (specifičan za Čile) odvija se između iseljenika i predstavnika JUO-a putem iseljeničkog tiska (službeno glasilo JNO-a pod uredništvom je prvo Ljube Leontića, potom Milostislava Bartulice).

Komunikacija se odvijala i na relacijama između Centra, ogranaka i Uprave JNO-a unutar južnoameričkog kontinenta ali i njihovim kontaktima s iseljeničkim pokretom u Sjevernoj Americi. O zajedničkim akcijama, kao što je istupanje južnoameričkih i sjevernoameričkih iseljenika 29. i 30. studenoga 1916. godine u Pittsburghu, govori nam sljedeći primjer:

Da ste nam zdravo braćo, okupljena za sveti ideal našeg oslobođenja! [...] Dolaze vam u posjete naši izaslanici naše Organizacije, da vam pokažu koliko je i kao Jugosloven Južne Amerike učinio za sreću našeg kraja, da vam iznesu dosadašnji rad, i da vam saopće da JNO ujedinjuje u svojoj organizaciji 23 ogranka po svim Republikama ovog južnog dijela Amerike [...] Bit će oni s vama na Kongresu, da stvorite nove zaključke, i da pobratimljeni zajednički i uporedo poradimo za spas naše zemlje; biće sa vama da se naše težnje poveću i da se naše snage ujedine, da se naša srdca približe - i da se naš opći rad krene istim putem. Bio svet taj lijepi trenutak narodne sloge i ljubavi [...] Neka bude veliki narodni sabor, gdje su predstavnici iseljenika, slobodni i svjesni, progovorili jako i učinili mnogo za našu slobodu. (Jugoslavenska država, 29. listopada 1916.)

Drugi primjer govori o komunikaciji koja se uspostavlja preko Leontića koji je u ime JNO-a radio na zajedničkim interesima i akcijama Jugoslavenskoga narodnog vijeća (JNV; iseljenički pokret u Sjevernoj Americi):

Jugoslavensko narodno vijeće u Sjevernoj Americi istupa ovdje redovno i u vaše ime, smatrajući se jednom nerazdruživom cjelinom sa Jugoslavenskom narodnom obranom u Južnoj Americi. Ta naša jedinstvenost podava veće značenje i moralnu snagu svakom našem poduzeću, a ujedno i proširuje krug našeg djelovanja. Na isti način i vi možete da istupate $u$ vašoj sredini računajući uvijek s našom solidarnosti. (Dopis JNV-a JNO-u, 11. studenoga 1918., u: Antić 1987:173) 
JNO je u transiseljeničkom prostoru imao političko-ekonomsku funkciju. Preuzeo je na sebe financiranje JO-a u Londonu. Financiranje je snosila grupa bogatih industrijalaca koji su stajali na čelnim pozicijama samog pokreta. ${ }^{34}$ Financiranjem JO-a ova je grupa iseljenika, što vlastitim interesom, što interesom kapitala kao reakcijom na crne liste, priskrbila sebi status uzoritih Jugoslavena i rodoljuba. Njihova financijska moć značila je i političku moć nad JO-om jer bi se zbog izostanka i obustavljanja novčane pomoći paralizirao i rad JO-a a potom i samog pokreta. Autoritet Paska Baburizze kao čelnog čovjeka Uprave JNO-a bio je važan za sam opstanak i razvoj pokreta. Kroz njegov je autoritet izgrađeno povjerenje i odnos prema JO-u i uspostavljeno je jedinstvo iseljeničke zajednice (većinskog dijela) kao bitan marker u definiranju nacionalnog identiteta. $U$ nacionalističkom jeziku, "jedinstvo" označava društvenu koheziju, bratstvo svih nacionalnih pripadnika u okviru nacije (Smith 1998:122).

Kako je vidljivo, nacionalna retorika polazi od pojmova ujedinjenja, jedinstvenosti i povezanosti cijelog naroda jedne nacije. Stoga se i komunikacijski kanali razgranavaju u cilju povezivanja svih, a okupljanje pripadnika istog naroda razasutog po različitim teritorijima i njihov ujedinjeni rad daju posebnu nacionalnu snagu i uspjeh nacionalnog pokreta.

Uz postojeće elemente hrvatske kulture - hrvatska zastava, hrvatska himna, slike hrvatskih vladara i sl. u skladu s novom definicijom države (po kojoj su Hrvati, Srbi i Slovenci jedan narod - Jugoslaveni) - pojavljuje se i unifikacija kulture troimenog naroda. Konstruira se jedan novi oblik kulture: jugoslavenska iseljenička kultura u kojoj dominiraju srpski kulturni elementi, kao što su srpska himna, srpska zastava, slavljenje

\footnotetext{
${ }^{34}$ Navodimo ukratko njihove životopise koristeći podatke iz iseljeničkog tiska i izvora Arhiva JNO-a: Pasko Baburizza, Dubrovčanin, bio je predsjednik JNO-a u Čileu i Južnoj Americi i počasni član Jugoslavenskog odbora u Londonu. Bio je vodeća osoba u salitrenoj industriji, vlasnik nekoliko tvrtki u Antofagasti, Valparaísu, Tarapaci s pet vlastitih osiguravajućih društava. Bio je član mnogih hrvatskih iseljeničkih društava koje je materijalno pomagao. Antun Lukšić, Bračanin, bio je uspješan trgovac, uvažen u privrednim krugovima Antofagaste. Član je i utemeljitelj Slavenskog društva uzajamne pomoći, Vatrogasnog društva br. 3 Dalmacija i Jugoslavenske škole. Jedan je od vođa JNO-a u Antofagasti. Franjo Petrinović, Bračanin, bio je ugledni privrednik, predstavnik velikih čileanskih tvrtki u Londonu i New Yorku. U Prvom svjetskom ratu izabran je za predsjednika JNO-a u Južnoj Americi.
} 
srpskog blagdana sv. Vida, srpske narodne pjesme, populariziranje srpske povijesti - njezinih vladara i narodnih junaka.

Uz elemente hrvatske i srpske kulture, zastupljeni su i čileanski odnosno argentinski (španjolski) utjecaji: čileanska ili argentinska zastava i himna, španjolski jezik koji se upotrebljava pri svakodnevnoj komunikaciji (iseljenika i domicilnog stanovništva, u ophođenju s drugim stranim konzulatima u Čileu, poneki i u obitelji), ali i kao pisani jezik iseljeničkog tiska (dvojezično hrvatsko-španjolski ili samo španjolski).

\section{ZAKLJUČAK}

Prvi svjetski rat, osim što je utjecao na svjetska gibanja uzrokujući nove političke podjele, odnose, preslagivanja i veze između različitih zemalja, doveo je i do nacionalnog samoodređenja naroda Monarhije, pa tako i Hrvata koji su u to vrijeme bili teritorijalno razdijeljeni unutar ugarskog i austrijskog dijela Monarhije. Dok su Hrvati u ugarskom dijelu imali određena prava i slobode potpisane Hrvatsko-ugarskom nagodbom, u Dalmaciji i Istri situacija je bila drugačija. Možda stoga nije slučajno kako je upravo u Dalmaciji popularnost južnoslavenske nacionalne ideje bila najizražajnija. Politički emigranti okupljeni u JO-u i u JUO-u u najvećem su broju podrijetlom bili Dalmatinci. Najveći broj iseljenika u Čileu i Argentini bili su Hrvati iz Dalmacije. Stoga je neosporna teza kako su Dalmatinci, unatoč određenim ekonomsko-političkim razlozima koji su sprečavali ili otežavali njihov društveno-kulturni razvoj, aktivno sudjelovali u održavanju svoje zajednice pa i onda kada nisu mogli teritorijalno biti vezani uz nju.

Nacionalni/etnički identiteti iseljenika konstruirani su utjecajem političkih događaja u domovini, a uglavnom putem iseljeničkih društava ili novina. Politički događaji - atentat na prijestolonasljednika Ferdinanda i Prvi svjetski rat - doveli su do političke podjele među iseljenicima. Podjela i dihotomizacija uspostavljena je kao odnos prema drugome: MI - ONI, Hrvati u odnosu na Srbe kao druge i različite, za grupu iseljenika koji su izjašnjavali Hrvatima (i težili samostalnoj državi Hrvatskoj u okviru Monarhije ili u okviru jugoslavenske federacije ali kao samostalne jedinice), i koji nisu pristajali na državu Jugoslaviju zajedno sa Srbima u kojoj će ime Hrvat biti zamijenjen Jugoslavenom. Druga grupa hrvatskih iseljenika uspostavila je dihotomizaciju naprama germanstvu i Austro-Ugarskoj 
Monarhiji kao neprijateljskim narodima/državama. Ova grupa iseljenika izjašnjavala se Jugoslavenima i zalagali su se za zajedničku državu južnih Slavena. Kod Hrvata-Jugoslavena, u cilju mobiliziranja i ujedinjenja iseljenika, kao i širenja grupe istomišljenika, koristila se "porodična metafora" odnosno genealoški pojam nacije (Smith 1998; Gellner 1998). Ove dvije političke grupe hrvatskih iseljenika istog su etničkog podrijetla, pa stoga svoje međusobno isključivanje i uspostavljanje granica nisu temeljile na osnovi kriterija etničnosti nego po načelu "tko se čijoj strani u ratu priklonio".

Brojčano i aktivnošću dominirala je grupa iseljenika HrvataJugoslavena koji su imali veliko uporište u JO-u, a JO veliku podršku u njima. Ovo se prije svega odnosi na iseljenike u Čileu gdje je ekonomski moćna elita skrivena pod imenom Upravni odbor JNO-a u cijelosti financirala JO, a autoritet i moć Baburizze držao čvrsto zajednicu HrvataJugoslavena na okupu. Unatoč toj činjenici, značajan broj u zajednici iseljenika Hrvata-Jugoslavena bili su mladi ljudi (demokrati, pristaše JUO-a) srednjega ekonomskog položaja koji su bili pokretačko bilo iseljeničkog pokreta. Oni su prije rata surađivali i bili političke pristalice ideja JUO-a, te su i u iseljeništvu zajedno s njim nastavili radikalnu politiku često se sukobljavajući s konzervativnom strujom imućnih iseljenika. Ovi sukobi nisu izazvali ozbiljniji poremećaj pokreta što potvrđuje tezu kako etnički/ nacionalni identitet ima jaču snagu nego ijedna druga vrsta kolektivnog identiteta poput klasnog, profesionalnog ili generacijskog identiteta. Jaka politička veza JO-a i iseljenika Hrvata-Jugoslavena bila je presudna za razvoj organiziranoga iseljeničkog političkog pokreta JNO. U Argentini je situacija biti drugačija, te unatoč različitim intervencijama JO-a i JUO-a nije imala snažnijeg odjeka. Autori (Antić, Leontić, Paulova i dr.) koji su se bavili ovom problematikom uzrok tomu nalazili su u različitim razlozima: velik utjecaj austrougarske vlasti i njihovih pristaša među iseljeništvom, socijalni status iseljenika u Argentini-značajan broj siromašnih, teritorijalno raspršenih i politički nezainteresiranih iseljenika. Prema našem mišljenju, iseljenički pokret JNO u Argentini nije uspio jer među iseljeništvom nije bilo, kao u Čileu, mlade, organizirane političke snage, a imućniji iseljenici ostali su vjerni Monarhiji, poglavito najveći autoritet među iseljenicima i ekonomski najmoćniji iseljenik Nikola Mihanović. Velik utjecaj imala je i propaganda intelektualca i novinara Radeljaka koji je unatoč okolnostima 
uspio očuvati i zadržati Hrvatski savez i iseljeničke novine Zajednica. Uza sve navedene faktore, najveći utjecaj imao je etnički sastav iseljeništva, odnosno stalni prikriveni jaz između hrvatskog i srpskog iseljeništva koji je imao različite faze, ali nikada unatoč južnoslavenskoj propagandi nije doveo do jedinstvene nacionalne integracije iseljenika koji su radije birali odvojene kolektivne strategije.

Pozicija hrvatskih iseljenika za vrijeme rata unutar Čilea i Argentine kao zemalja sa pozicijom neutralnih država i nije bila laka. Unatoč statusu u Čileu i Argentini, presudio je kapital savezničkih zemalja koji je diktirao ekonomsko-političke uvjete u ovim državama. Stoga je dio iseljenika koji se vodio situacijskim okolnostima i racionalnom logikom, a na kraju i ekonomskim interesima, izabrao južnoslavensku nacionalnu koncepciju, prihvatljivu Saveznicima. Poslužimo li se teorijom racionalnog izbora, ovaj preokret možemo pojasniti sljedećim riječima: “... članovi te grupe nisu definirani na osnovu svoje nedobrovoljne pripadnosti, već se one obrazuju kada pojedinci žele da zadobiju određeno dobro (bogatstvo, moć, utjecaj), do kojih ne uspijevaju doći individualnom strategijom" (Poutignat i Streiff-Fenart 1997:112). Hrvati-Jugoslaveni ojačali su svoju grupu/ zajednicu ekonomski moćnim pojedincima što je išlo u prilog i JO-u. Ovaj proces “popunjavanja redova" nalazimo i u Čileu i u Argentini, ali različitog intenziteta. U Čileu je imao snažniji utjecaj jer su unutar njega ušli svi imućni iseljenici, dok je u Argentini obuhvatio samo manji dio iseljenika, a većina "imućnih iseljenika" ostala je po strani, vjerna Monarhiji.

Kako je u pitanju nacionalni pokret zajednički narodu u domovini i iseljeništvu tako je uspostavljena mrežna komunikacija između važnih punktova narodnih predstavnika i organizacija te njihova stalna mobilnost, pozicioniranje s obzirom na vanjske okolnosti i izmijenjene situacije. Mogli bismo reći kako se događao transnacionalizam ili nacionalizam na daljinu, koji je svojom snagom, mnogostrukim vezama i pozicijama ukidao, transformirao i transcendirao nacionalne granice. Iseljenici u Čileu i Argentini, oni koji su bili unutar iseljeničkog pokreta, "komunicirali" su sa svojim istomišljenicima i u drugim državama Južne i Sjeverne Amerike, a preko JO-a i s istomišljenicima u Europi. Kao pristaše Saveznika bili su i u vezi s iseljeničkim savezničkim kolonijama predstavljajući svoju poziciju na način "onih koji su na istoj strani”. Kroz različite primjere rekonstruirali 
smo nacionalistički jezik i tip nacionalizma i zaključili kako se ponajprije oslanjao na sentiment, simbole i ceremonije gdje je vidljiva dominacija i penetracija srpskih elemenata kulture. Kako se nacionalizam odvijao i u prostoru "iseljene domovine", u tom je prostoru razvijao specifična obilježja. Hrvatska nacionalna koncepcija zamijenjena je jugoslavenskom, pa s pravom možemo tvrditi da se u ovom razdoblju utjecajem iseljeničkog pokreta i iseljeničkog tiska provodila jugoslavenizacija hrvatskih iseljeničkih kolonija. Pisanje Slobode i Zajednice da se ne odriču hrvatskog imena te da pristaju na Jugoslaviju, ali jedino pod uvjetom da ona bude utemeljena kao federacija, nije polučilo uspjeha. Obilatom novčanom pomoći i čuvanju ugleda i legitimiteta JO-u od strane hrvatskih ekonomskih poduzetnika iz Čila stvorena je Kraljevina SHS odnosno Kraljevina Jugoslavija.

\section{LITERATURA}

AGIČIĆ, Damir. 1996. "Civil Croatia on the Eve of the First World War (The Echo of the Assassination and Ultimatum)". Povijesni prilozi, vol. 14:301-317.

ANTIĆ, Ljubomir. 1987. Naše iseljeništvo u Južnoj Americi i stvaranje jugoslavenske države 1918. Zagreb: Školska knjiga.

BANOVIĆ, Branimir. 1987. "Emigracijska politika Austro-Ugarske i iseljavanje iz Hrvatske u razdoblju 1867-1914". Migracijske teme, vol. 3-4:313-325.

DIKLIĆ, Marijan. 1998. Pravaštvo u Dalmaciji do kraja Prvoga svjetskoga rata. Zadar: Matica hrvatska - Zavod za povijesne znanosti HAZU u Zadru.

GANZA-ARAS, Tereza. 1992. Politika novog kursa dalmatinskih pravaša oko Supila $i$ Trumbića. Split: Matica hrvatska.

GELLNER, Ernest. 1998. Nacije i nacionalizam. Zagreb: Politička kultura.

GOLDSTEIN, Ivo. 2003. Hrvatska povijest. Zagreb: Novi liber.

KARAULA, Željko. 2011. "Sarajevski atentat - reakcije Hrvata i Srba u Kraljevini Hrvatskoj, Slavoniji i Dalmaciji”. Radovi Zavoda za hrvatsku povijest Filozofskoga fakulteta Sveučilišta u Zagrebu, vol. 43/1:255-291.

LAJIĆ, Ivan. 1992. Stanovništvo dalmatinskih otoka. Zagreb: Institut za migracije i narodnosti.

LAKATOŠ, Josip. 1914. Narodna statistika. Zagreb: Vlastita naklada.

LEONTIĆ, Ljubomir. 1961. O Jugoslovenskom odboru u Londonu. Zagreb: Izdavački zavod Jugoslavenske akademije.

MACHIEDO MLADINIĆ, Norka. 2007. "Prilog proučavanju djelovanja Ivana Meštrovića u Jugoslavenskom odboru”. Časopis za suvremenu povijest, vol. 39/1:133-156. 
ORŠOLIĆ, Tado. 2006. “O časničkoj izobrazbi, plaći i časničkom kadru austrougarske vojske s naglaskom na Dalmaciju”. Radovi Zavoda za povijesnih znanosti HAZU u Zadru, vol. 48:557-568.

PAULOVA, Milada. 1924. Jugoslavenski odbor. Zagreb: Poslovna nakladna zadruga.

PAVLIČEVIĆ, Dragutin. 2000. Povijest Hrvatske. Zagreb: Naklada Pavičić.

PERIĆ, Marina. 2005. "Hrvatski salitreri na sjeveru Čilea”. Hrvatska revija, vol.1:112116.

PERIĆ, Marina. 2006. "Političke promjene u Hrvatskoj i hrvatski iseljenički tisak u Čileu”. Migracijske i etničke teme, vol. 21/1-2:69-89.

PERIĆ KASELJ, Marina. 2014. "Politički transnacionalizam hrvatskih iseljenika u Čileu: povezivanje hrvatskih i srpskih iseljenika i iseljenički pokret JNO”. U Serb-Croat political relations in the 20th century - identity protection / Srpsko-hrvatski politički odnosi u 20. veku - zaštita identiteta. Sedmi međunarodni naučni skup, Golubić (Obrovački), zbornik radova, ur. Darko Gavrilović. Novi Sad - Golubić: Centar za istoriju, demokratiju i pomirenje, 7-17.

POUTIGNAT, Philippe i Jocelyne STREIFF-FENART. 1997. Teorije o etnicitetu. Zemun - Beograd: Biblioteka XX vek - Čigoja štampa.

ROJNICA, Ivo. 1974. Prikaz povijesti Argentine. Buenos Aires: Vlastita naklada.

SMITH, Anthony D. 1998. Nacionalni identitet. Zemun - Beograd: Biblioteka XX vek Čigoja štampa.

\section{ISELJENIČKE NOVINE}

Domovina (1908.-1913.), Punta Arenas

Iseljenik (1925.), Zagreb

Jadran (1915.-1920.), Buenos Aires

Jugoslavija (1925.-1932.), Buenos Aires

Jugoslovenska država (1916.), Antofagasta

Jugoslovensko oslobođenje (1918.), Antofagasta

Novi iseljenik (1929.), Zagreb

Novo doba (1910.-1911.), Punta Arenas

Pokret (1914.-1916). Antofagasta

Sloboda (1902.-1906.), Antofagasta

Zajednica (1910.-1916.), Rosario 
Marina Perić Kaselj

\section{HOW WE BECAME YUGOSLAVS: ON ETHNIC/NATIONAL IDENTITIES OF CROATS IN CHILE AND ARGENTINA DURING WWI}

WWI and the events that ensued during and after the war had a strong impact on the immigrants' collective identity. National self-determination of Croats in or outside of the Monarchy, on the trilateral foundation with The Austro-Hungarian Monarchy or in the association with the South Slavic nations, imposed themselves as the dominant national ideology in the homeland. The same political situation was also evident among the immigrant communities in Chile and Argentina. Events such as WWI changed the collective identity and strategies of the Croatian emigrants in Chile and Argentina, whereby a new national definition and South Slavic concept of a future state was promoted by the immigration press and emigrant associations. Consequently, the immigrant movement Yugoslav People's Defence (JNO) in South America was established. Using the emigrant press as a source, in order to find the dominant discourse in shaping emigrants' collective consciousness, in this paper we are trying to answer the questions of how the events in the homeland, WWI in particular, had affected the collective identity of immigrants in Chile and Argentina. The article analyzes the factors that contributed to the strong support and participation of immigrants in the Chile emigrant movement JNO (as opposed to immigrants in Argentina) as well as their role in creating the future state of Serbs, Croats and Slovenes/Yugoslavia (SHS/Jugoslavija).

Keywords: Croatian emigrants, Chile, Argentina, WWI, ethnic/national identity, immigration movement, the Yugslav National Defence

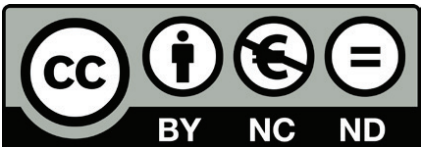

Articles published in this journal are Open Access and can be distributed under the terms and conditions of the Creative Commons license Attribution-NonCommercial-NoDerivatives 4.0 (http://creativecommons.org/licenses/by-nc-nd/4.0/) 
